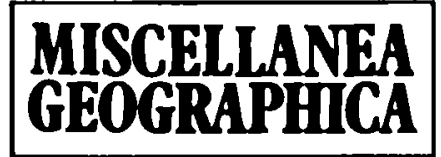

WARSZAWA 1992 Vol. 5

Anna Achmatowicz-Otok

\title{
SURVEY OF SETTLEMENT LANDSCAPE AESTHETICS IN POLAND
}

The geographical research of landscape aesthetics in regard to State social policy was first started in Poland in 1987. It is carried out under the theme "Environment in Social Policy of the State". Institutionally, the research was coordinated by the Department of Social Geography, University of Warsaw.

The research group of the University of Akron (USA), of the University College of Swansea (Great Britain) and of Moscow University was subdivided into three sub-groups:

1. Research on the appearance of cities and settlements;

2. Polish cultural landscape protection: a revision of policy and organization of protection;

3. Research on the social perception and attitude to landscape aesthetics in Poland.

\section{THE DEFINITIONS}

The topic of research is an aesthetics of landscape of settlements and their closest surroundings in Poland.

The landscape is the appearance (the external look) of geographical environment. Landscape is estimated and evaluated as a synthesis of integrated perceptions of various views and related attitudes and associations codified in the observer's mind.

Landscape aesthetics is understood as a reflection of social processes taking place among inhabitants and as a result of the policy of the State and governmental institutions towards the society.

Research problems:

1. How far does landscape aesthetics provide the psychical comfort for the particular social groups in Poland?

2. What should be done to improve the aesthetics of Polish landscape, in what direction should this activity be conducted and who should undertake it?

3. Which of selected elements of Polish landscape are most valuable in the social perception?

4. Who in the social perception is responsible for the landscape aesthetics in Poland? 


\section{QUESTIONNAIRE}

The main research tool was a three-page questionnaire, on the basis of which interviews were conducted with selected inhabitants of some chosen districts and areas.

The questionnaire included:

- the positive and negative evaluation of closest surroundings (house, street, selected objects, settlement, city district, city, park);

- the pointing out of the most valuable and the prettiest objects of an area, settlement, city district, city;

- the construction style preferences, the settlement preferences;

- the perception of monuments in an area, city district and city;

- the characteristics of the closest surroundings (house possession, sanitary conditions, such as water, sewer, waste; organization of sanitary level maintenance in the living place; discomfort of the surroundings (bothering neighbours, noisy city transport close by, air pollution);

- the evaluation of harmony of new constructions with existing buildings and natural environment;

- pointing out the institutions and persons responsible for appearance and aesthetics of an area, and for environmental protection in close and further surroundings;

- social and demographic characteristics of respondent (sex, age, education, period of residence in the place, profession).

\section{THE RESEARCH AREA}

The research area were 21 cities (including: Warsaw, five voivodship capital cities, fifteen smaller cities) and 38 villages situated in all parts of Poland.

Selection of the place in the area was done according to:

- types of construction (one-family housing, two-family and multi-family housing),

- age of construction (constructed before 1945, after 1945, brand new),

- level of disrepair (approximately).

Selection of respondents was done according to sex, age, level of education, length of residence.

\section{THE RESULTS OF PRIMARY RESEARCH}

The first results of primary research permit the formulation of general answers to research questions asked above. 
1.How far do the landscape characteristics provide the Polish society with psychic comfort?

The result of positive and negative evaluation for closest (up to 200 metres) and the farther (more than 200 metres) surroundings revealed a prevalent negative evaluation of the street landscape as well as of settlement, city district, and the city estimates (see Table 1). The strongest response among the respondents was in the evaluation of closest surroundings (the street) and the most distant surroundings (the city as a whole). In evaluation of landscape aesthetics of these areas we got no more than $50 \%$ responses.

Table 1

Landscape aesthetics in Poland

\begin{tabular}{|c|c|c|c|c|c|c|c|c|c|c|c|c|c|}
\hline \multirow[t]{2}{*}{ Landscape } & \multicolumn{2}{|c|}{ Street } & \multicolumn{2}{|c|}{ Settlement } & \multicolumn{2}{|c|}{ City district } & \multicolumn{2}{|c|}{ City } & \multicolumn{4}{|c|}{ Points } & \multirow[t]{2}{*}{ Total } \\
\hline & $\begin{array}{c}\% \\
\text { yes }\end{array}$ & $\begin{array}{l}\% \\
\text { no }\end{array}$ & $\begin{array}{c}\% \\
\text { yes }\end{array}$ & $\begin{array}{l}\% \\
\text { no }\end{array}$ & $\begin{array}{c}\% \\
\text { yes }\end{array}$ & $\begin{array}{l}\% \\
\text { no }\end{array}$ & $\begin{array}{c}\% \\
\text { yes }\end{array}$ & $\begin{array}{l}\% \\
\text { no }\end{array}$ & st reet & settl. & $\begin{array}{l}\text { city } \\
\text { dis. }\end{array}$ & city & \\
\hline \multicolumn{14}{|c|}{ negative valuation } \\
\hline too dark & 33.4 & 66.6 & 12.1 & 87.9 & 12.0 & 88.0 & 26.6 & 73.4 & 8 & 5 & 4 & 6 & 23 \\
\hline $\begin{array}{l}\text { sometimes } \\
\text { dirty }\end{array}$ & 32.1 & 67.9 & 22.2 & 77.8 & 21.5 & 78.5 & 33.3 & 66.7 & 7 & 7 & 8 & 8 & 30 \\
\hline gray & 27.1 & 72.9 & 23.8 & 76.2 & 20.1 & 79.9 & 29.2 & 70.8 & 6 & 8 & 7 & 7 & 28 \\
\hline monotonous & 17.0 & 83.0 & 19.5 & 80.5 & 12.3 & 87.7 & 17.7 & 82.3 & 5 & 6 & 5 & 4 & 20 \\
\hline damaged & 15.7 & 84.3 & 12.0 & 88.0 & 14.1 & 85.9 & 19.0 & 81.0 & 4 & 4 & 6 & 5 & 19 \\
\hline ugly & 13.8 & 86.2 & 9.2 & 90.8 & 5.8 & 94.2 & 7.9 & 92.1 & 3 & 3 & 3 & 2 & 11 \\
\hline $\begin{array}{l}\text { permanently } \\
\text { dirty }\end{array}$ & 7.4 & 92.6 & 5.2 & 94.8 & 4.4 & 95.6 & 10.7 & 89.2 & 2 & 2 & 2 & 3 & 9 \\
\hline too coloured & 0.4 & 99.6 & 0.7 & 99.3 & 0.5 & 99.5 & 0.6 & 99.4 & 1 & 1 & 1 & 1 & 4 \\
\hline \multicolumn{14}{|c|}{ positive valuation } \\
\hline pretty & 35.0 & 65.0 & 33.2 & 66.8 & 35.2 & 64.8 & 49.0 & 51.0 & 5 & 5 & 5 & 5 & 20 \\
\hline weel lighted & 27.4 & 72.6 & 15.2 & 84.8 & 9.7 & 90.3 & 10.0 & 90.0 & 4 & 4 & 3 & 2 & 13 \\
\hline clean & 22.0 & 78.0 & 14.4 & 85.6 & 6.6 & 93.4 & 14.4 & 85.6 & 3 & 3 & 2 & 3 & 11 \\
\hline attractive & 7.4 & 92.6 & 9.9 & 90.1 & 13.7 & 86.3 & 19.2 & 80.8 & 2 & $\underline{2}$ & 4 & 4 & 12 \\
\hline $\begin{array}{l}\text { in good } \\
\text { architect. } \\
\text { style }\end{array}$ & 2.8 & 93.2 & 3.0 & 97.0 & 3.5 & 96.5 & - & - & 1 & 1 & 1 & - & - \\
\hline
\end{tabular}

Generally, the streets in Poland were evaluated by respondents as: too dark, sometimes dirty, grey, with monotonous construction. The settlements were evaluated as grey, sometimes dirty with monotonous construction, too dark. The city districts in Polish cities were evaluated as sometimes dirty, grey, too dark, in disrepair.

Generally, in the negative evaluation of landscape aesthetics in Poland the following descriptions prevailed:

$\begin{array}{ll}\text { sometimes dirty } & 30 \text { points } \\ \text { grey } & 28 \text { points } \\ \text { too dark } & 23 \text { points }\end{array}$


General positive evaluation of landscape aesthetics shows that Polish landscape settlements were considered as:

$\begin{array}{ll}\text { pretty } & 20 \text { points } \\ \text { well lighted } & 13 \text { points } \\ \text { attractive } & 12 \text { points }\end{array}$

In this number the streets and settlements were evaluated mainly as pretty and well lighted but city districts and cities as pretty and attractive.

Obviously, the sanitary conditions influence the perception of landscape aesthetics in the respondent's dwelling place. During the period under study $16.4 \%$ of respondents were using out houses in the backyard. In the opinion of $1.5 \%$ those were stinking and in the opinion of $1.4 \%$ they were often dirty. $10.3 \%$ of respondents noticed discomfort resulting from the open disposal in the road ditch, and $7.6 \%$ in the forest close to their dwelling place.

Over $60 \%$ of respondents were using city sewer system, but over $10 \%$ do not have the sewer at all. $6.8 \%$ of respondents noticed smelly sewer disposal in their dwelling place, and $7.5 \%$ asserted that their own sewer emptying is difficult from the organizational point of view.

2. Which of the social groups are most sensitive to psychic discomfort in the area under research?

Among the persons evaluating negatively the landscape aesthetics in their dwelling place the largest social groups were (see Table 2):

- inhabitants at the age group between 25 to 55 years old,

- people with elementary education and not finished high school,

- unemployed,

- professionals,

- inhabitants living in the place for twenty years and over.

Table 2

Poland. Aesthetics landscape. Negative valuation by social groups.

\begin{tabular}{|l|r|}
\hline Age: & \\
$25-55$ years old & $59.5 \%$ \\
55 years and more & $32.5 \%$ \\
\hline Education: & \\
Primary school and secondary school & $43.2 \%$ \\
high school & $40.9 \%$ \\
\hline Occupation: & \\
unemployment & $28.2 \%$ \\
professionals & $21.5 \%$ \\
clerks & $19.1 \%$ \\
farmers & $12.4 \%$ \\
& $8.0 \%$ \\
\hline Period of residence: & \\
more then 20 years & $42.9 \%$ \\
$0-10$ years & $28.3 \%$ \\
\hline
\end{tabular}


3. Which elements of Polish landscape are most valuable in social perception?

The respondents have chosen mainly:

- the monumental religious constructions (churches, cathedrals, monasteries) $-20.7 \%$,

- the public utility objects - $19.1 \%$,

- the groups of monumental architecture (parts of cities, palaces, Old Town, Old Market Square, Wilanow Palace complex) - 10.3\%.

Also, over $17 \%$ of respondents rejected the question answering: "I like nothing","What was valuable was destroyed", "I am not interested in it "(3.4\%).

The question about perception of the monuments standing on the market squares and streets of Polish cities and settlements, showed that the monuments of creators of Polish national culture (writers, poets, composers) met the greatest respect $(14 \%)$. About $60 \%$ of respondents expressed negative feelings towards monuments of the squares and streets (built after 1945) responding:

"I do not like monuments," "These are their monuments," "These are not our monuments;" not responding at all, or giving aggressive and negative responses.

The responsibility for the landscape aesthetics in Poland was attributed by the respondents mainly to inhabitants, house managers by their caretakers and architects.

Particularly interesting is the preference of type of house the respondents would like to live in. Close to $75 \%$ of respondents are dreaming about one-family houses. The motivation is:

$\begin{array}{lr}\text { quiet, privacy, guarrantee of quiet time } & 28 \% \\ \text { functional factors } & 16 \% \\ \text { aesthetic factors } & 13 \% \\ \text { the garden and green space } & 8 \%\end{array}$

\section{CONCLUSION}

The main task of primary research was to grasp the perception and attitude of respondents. The results show that the large part of respondents evaluate negatively the landscape aesthetics in their dwelling place. The social groups representing the negative perception and attitude consist mainly of people of 25-55 years of age, of polarized qualifications: very high qualifications (professionals) and very low ones as well as unemployed; residence period varies from very long - over 20 years to short - up to 10 years.

The attitude of the respondents toward the historical landscape is positive. The negative attitude is expressed in aggressively negative answers connected with particular monuments on the squares and streets. The monuments in Poland are considered as symbols of past and present. 
The indication for the social policy is that the following procedures and structures should by revised:

Poland;

1. the organization of range of responsibility for the landscape aesthetics in

2. the effectiveness and proceeding of local public services;

3. the effectiveness and procedure of environmental protection, particularly as regards air and water pollution;

4. the settlement preferences of the social groups should be investigated, particularly in the context of type of housing and social neigbourhood, to lower the number of newly constructed apartments with the prevalence of one-family housing.

The first indications for the future research are:

1. to recognize which type of landscape is the most valuable for Poles, where they would like to live;

2. is there a "Polish landscape" in social perception and what are its attributes?

\section{REFERENCES}

Achmatowicz-Otok A., Ot ok S., 1988," Social Aspects of Transformation in the Physiognomy of Buildings," in: S.Otok (ed.), Research Approach to Social Geography, Wydzial Geografii i Studiów Regionalnych UW, pp.59-68.

A chmatowicz-Otok A., "Problems of Landscape Aesthetics in Social Policy in Poland," in: S. Otok, Environment in Social Policy of the State", Wydzial Geografii i Studiów Regionalnych UW, pp.79-88.

A ch mat owicz-Otok A., 1990," Estetyka krajobrazu w polityce społecznej państwa. Synteza końcowa" (Landscape Aesthetics in Social Policy of the State. Final Report), in: S. Otok (ed.), Srodowisko naturalne w polityce spolecznej państwa, (Natural Environment in Social Policy of the State), Ośrodek Badań Społecznych, Warszawa, pp.159-182.

Noble A., A ch matowicz-O tok A., 1990, "Perception of Housing and Community Conditions in Suburban Settlement of Warsaw, Poland." in: Applied GeographyConferences, Vol.13, Binghamton, New York, pp.227-232.

Dutt A., Achmatowicz-Otok S.,Jr., Achmatowicz-Otok A., 1991, Residential Preferences in the City of Warsaw, Poland, GeoJournal (July), Kluwer Academic Publishers, Dordrecht- Boston-London. 